\title{
PERBEDAAN ANGKA KEJADIAN GINGIVITIS ANTARA USIA PRA-PUBERTAS DAN PUBERTAS DI KOTA MALANG
}

\author{
Diah*, Trining Widodorini**, Nandia Enggar Nugraheni*** \\ * Departemen Periodonsia Fakultas Kedokteran Gigi Universitas Brawijaya, Malang \\ ** Departemen IKGMP Fakultas Kedokteran Gigi Universitas Brawijaya, Malang \\ *** Program Studi Sarjana Kedokteran Gigi Fakultas Kedokteran Gigi Universitas Brawijaya, \\ Malang \\ Korespondensi: Diah, E-mail: diahloekito@yahoo.com
}

\begin{abstract}
ABSTRAK
Gingivitis merupakan inflamasi yang mengenai jaringan gingiva yang disebabkan oleh plak. Salah satu faktor predisposisi gingivitis adalah ketidakseimbangan hormon endokrin pada waktu pubertas. Peningkatan kadar hormon endokrin selama usia pubertas menyebabkan vasodilatasi jaringan gingiva yang mengakibatkan gingivitis. Tujuan: untuk mengetahui perbedaan angka kejadian gingivitis antara usia prapubertas dan usia pubertas di kota Malang. Metode: Jenis penelitian ini survei analitik dengan pendekatan crosssectional. Teknik pengambilan sampel adalah purposive sampel. Pemeriksaan skor gingivitis dengan Modified Gingival Index (MGI). Hasil: skor gingivitis pada 33 usia prapubertas didapatkan $81,8 \%$ gingivitis ringan, $18,2 \%$ termasuk sehat, sedangkan skor gingivitis 33 usia pubertas didapatkan $90,9 \%$ gingivitis ringan, 9,1\% gingivitis sedang. Analisis data menggunakan uji fisher exact test dan coefisien contingency menunjukkan bahwa terdapat perbedaan angka kejadian gingivitis usia prapubertas dan pubertas di kota Malang. Kesimpulan: angka kejadian gingivitis usia prapubertas lebih rendah dibandingkan dengan usia pubertas.
\end{abstract}

Kata kunci: gingivitis, prapubertas, pubertas, Modified Gingival Index (MGI) 


\title{
DIFFERENCE OF GINGIVITIS GENERAL EVENTS BETWEEN PRE-PUBERTAS AND PUBERTAS AGE IN THE MALANG CITY
}

\begin{abstract}
Gingivitis is an inflammation of gum caused by the accumulation of plaque. One of the predisposition factors of gingivitis is endocrine hormone's imbalance in the pubertal period. The increasing endocrine hormone levels during puberty cause vasodilatation that increases blood circulation to the gingival tissue, it can result in gingivitis. Objectives: to know the difference of gingivitis prevalence between prepubertal and pubertal in Malang. Methode: The research type is an analytical survey with approach cross-sectional. The samples technique using the purposive sample. Gingivitis score was valued by Modified Gingival Index (MGI). Result: The value gingivitis score of this research showed gingivitis score of 33 prepubertal is $81,8 \%$ mild gingivitis and 18,2\% healthy, gingivitis score of 33 pubertal is 90,9\%mild gingivitis and 9,1\% moderate gingivitis. The data of this research was analyzed using the Fisher exact test and confine contingency, probability value obtained in this research showed that there is a significant difference of gingivitis prevalence between prepubertal and pubertal in
\end{abstract} Malang. Conclusion: Gingivitis prevalence in prepubertal less than pubertal.

Keywords: gingivitis, prepubertal, pubertal, Modified Gingival Index (MGI)

\section{PENDAHULUAN}

Gingivitis

merupakan suatu inflamasi yang melibatkan jaringan lunak di sekitar gigi yaitu jaringan gingiva. ${ }^{1}$ Gambaran klinis gingivitis adalah munculnya warna kemerahan pada margin gingiva, pembesaran pembuluh darah di jaringan ikat subepitel, hilangnya keratinisasi pada permukaan gingiva dan pendarahan yang terjadi pada saat dilakukan probing. ${ }^{2}$
Prevalensi gingivitis di Kota Malang pada bulan Agustus 2017, pada kelompok anak usia 5-9 tahun sebanyak 1.164 kasus dan pada kelompok anak usia 10-14 tahun sebanyak 922 kasus. Menurut data 10 penyakit terbanyak Puskesmas Gribig pada bulan Agustus 2017, gingivitis termasuk dalam 10 besar kasus penyakit terbanyak yakni menduduki urutan 3 dengan jumlah 204 kasus. 
Penyebab gingivitis dibagi menjadi dua, yaitu penyebab utama dan penyebab predisposisi. Penyebab utama gingivitis adalah penumpukan mikroorganisme yang membentuk suatu koloni kemudian membentuk plak gigi yang melekat pada tepi gingiva. Penyebab sekunder gingivitis berupa faktor lokal dan faktor sistemik. Faktor lokal meliputi karies, restorasi yang gagal, tumpukan sisa makanan, gigi tiruan yang tidak sesuai, pemakaian alat orthodonsi dan susunan gigi geligi yang tidak teratur, sedangkan faktor sistemik meliputi faktor nutrisional, faktor hormonal, hematologi, gangguan psikologi dan obatobatan. ${ }^{1}$

Faktor hormonal yang menjadi faktor predisposisi gingivitis tersebut salah satunya adalah ketidakseimbangan hormon yaitu peningkatan hormon endokrin pada usia pubertas. $^{3}$ Peningkatan hormon endokrin selama usia pubertas dapat menyebabkan vasodilatasi pembuluh darah dan meningkatnya kepekaan iritasi lokal, seperti biofilm plak bakteri, yang mengakibatkan gingivitis pubertas. ${ }^{4}$ Gingivitis pubertas adalah salah satu jenis dari gingivitis yang kadang-kadang berkembang pada anak-anak dan pubertas dengan keadaan plak yang sedikit dan bahkan sangat sedikit. ${ }^{5}$

Tingginya prevalensi untuk gingivitis pada anak telah dilaporkan dari beberapa bagian dunia. ${ }^{6}$ Berdasarkan survei Sutcliffe dari kelompok anak yang berusia antara 12 sampai 17 tahun menunjukkan prevalensi gingivitis yang tinggi yang cenderung menurun dengan bertambahnya usia. $^{5}$ Penelitian yang telah dilakukan di Bangladesh menunjukkan bahwa prevalensi peradangan gingiva lebih tinggi pada siswasiswi di pedesaan sebesar 22,5\% daripada di daerah perkotaan sebesar 13,9\%. Untuk perbandingan kelas sosial, prevalensi peradangan gingiva lebih tinggi pada siswasiswi dari kelas sosial yang lebih rendah daripada siswa-siswi dari kelas sosial yang lebih tinggi. ${ }^{7}$

Menurut data Dinas Kesehatan Kota Malang bulan November 2015 menyatakan bahwa gingivitis terbanyak ditemukan pada Puskesmas Gribig yang terletak di Kecamatan Kedungkandang, yakni sebanyak 2.721 kasus. Penelitian ini mengambil sampel siswa usia prapubertas dan siswa usia pubertas di Malang

\section{METODE PENELITIAN}

Desain penelitian ini merupakan suatu penelitian survei analitik dengan pendekatan cross-sectional. ${ }^{8}$ Sampel yang diambil dalam penelitian ini adalah seluruh siswa prapubertas kelas $\mathrm{V}$ di SDN Madyopuro 6 sebanyak 33 siswa dan siswa pubertas kelas VIII A di SMPN 22 Malang dengan jumlah 33 siswa yang memenuhi kriteria inklusi. Teknik pengambilan sampel yang akan digunakan pada penelitian ini adalah purposive sampling, yaitu pengambilan sampel dengan cara menetapkan ciri-ciri khusus yang sesuai dengan tujuan penelitian sehingga dapat menjawab permasalahan penelitian ${ }^{8}$ 
Kriteria inklusi sampel adalah siswa usia prapubertas yang memenuhi kriteria sebagai berikut:

1. Sampel berjenis kelamin laki-laki dan perempuan

2. Sampel berusia prapubertas 9-11 tahun pada laki-laki yang belum akil balig dan perempuan yang belum mengalami menstruasi

3. Sampel bersedia mengikuti penelitian dan mengisi informed consent

4. Sampel mengikuti proses belajar mengajar pada saat penelitian

Siswa usia pubertas yang memenuhi kriteria sebagai berikut:

1. Sampel berjenis kelamin laki-laki dan perempuan

2. Sampel berusia pubertas $12-16$ tahun pada laki-laki yang akil balig dan 11-15 tahun pada perempuan yang sudah mengalami menstuasi

3. Sampel yang berusia 9-11 tahun sudah pubertasdisesuaikan dengan kematangan biologis

4. Sampel bersedia mengikuti penelitian dan mengisi informed consent

5. Sampel mengikuti proses belajar mengajar pada saat penelitian

Kriteria Eksklusi sampel adalah sampel sedang dalam perawatan orthodonsi, memakai gigi tiruan. Variabel bebas (independent) pada penelitian ini adalah usia prapubertas dan usia pubertas. Dengan skala data nominal dua kategori. Variabel terikat (dependent) pada penelitian ini adalah kejadian gingivitis dengan skala data nominal tiga kategori.
Penelitian akan dilakukan di lokasi yang berada pada 1 kelurahan yakni SDN 6 Madyopuro dan SMPN 22 Malang. Penelitian dilakukan bulan Desember 2017.

Apabila sampel penelitian semua terpenuhi sesuai kriteria inklusi, maka dilakukan pemeriksaan angka kejadian gingivitis dengan menggunakan Modified Gingival Index (MGI) yang dirancang oleh Lobene et al (1986). MGI merupakan metode untuk mengukur keadaan gingiva pada individu atau populasi dengan cara memeriksa 4 bagian gingiva per gigi (dua marginal, dua papila). Nilai rata-rata individu dapat dihitung dengan menjumlahkan nilai unit gingiva dan membaginya dengan jumlah unit gingiva yang diperiksa. Skor tiap gigi $=$ jumlah skor 4 , permukaan gingiva yang diperiksa $=4$, Skor individu $=$ jumlah skor tiap gigi, jumlah gigi yang diperiksa. Kriteria skor adalah:

Skor 0: tidak adanya peradangan

Skor 1: peradangan ringan atau dengan sedikit perubahan dalam warna dan tekstur tapi tidak di semua bagian dari margin gingiva atau papila gingiva

Skor 2: peradangan ringan, seperti kriteria sebelumnya, di semua bagian-bagian dari margin gingiva atau papila gingiva

Skor 3: sedang, permukaan terang pada daerah peradangan, eritema, edema dan atau hipertrofi margin gingiva atau papila gingiva

Skor 4: peradangan parah, eritema, edema dan atau hipertrofi margin gingiva atau papila gingiva dari perdarahan spontan, mengumpul dan bisa mengalami ulserasi. ${ }^{9}$ 
Analisis data menggunakan fisher exact test. Selanjutnya apabila ada hubungan, dilanjutkan dengan uji coeficien contingency untuk mengetahui kuat hubungannya.

\section{HASIL PENELITIAN}

Skor gingivitis prapubertas di SDN Madyopuro 6 lebih baik dengan 18,2\% (6 orang) dengan kategori sehat, $81,2 \%$ (27 orang) dengan kategori ringan dibandingkan dengan skor gingivitis pubertas di SMPN 22
Malang dengan $90.9 \%$ (30 orang) dengan kategori ringan dan 9,1\% (3 orang) dengan kategori gingivitis sedang.

Hasil analisis statistik dengan fisher exact test diperoleh hasil besar $X^{2}$ hitung adalah 8,840 dengan $p$ value 0,006 kemudian dilanjutkan dengan perhitungan besar coefisien contingency didapat nilai $\mathrm{R}=$ 0,349 (hubungan lemah).

Tabel 1. Distribusi Kategori Skor Gingivitis

\begin{tabular}{c|c|c|c|c|c|c|c|c}
\hline \multirow{2}{*}{ Variabel } & \multicolumn{6}{|c|}{ Kategori Skor Gingivitis } & \multicolumn{3}{c}{ Total } \\
\cline { 2 - 9 } & \multicolumn{2}{|c|}{ Sehat } & \multicolumn{2}{c|}{ Ringan } & \multicolumn{2}{c|}{ Sedang } & \multicolumn{2}{c}{} \\
\cline { 2 - 9 } & $\mathrm{n}$ & $\%$ & $\mathrm{~N}$ & $\%$ & $\mathrm{n}$ & $\%$ & $\mathrm{n}$ & $\%$ \\
\hline Prapubertas & 6 & 18,2 & 27 & 81,8 & 0 & 0 & 33 & 100 \\
\hline Pubertas & 0 & 0 & 30 & 90,9 & 3 & 9,1 & 33 & 100 \\
\hline
\end{tabular}

\section{Grafik Distribusi Kategori Skor Gingivitis}

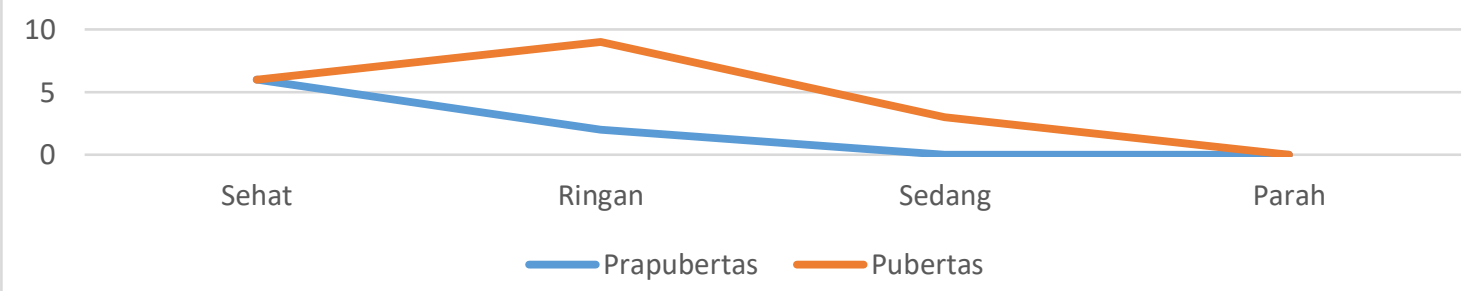

\section{Gambar 1. Grafik Distribusi Kategori Skor Gingivitis}

\section{PEMBAHASAN}

Berdasarkan hasil uji komperasi Fisher exact test didapatkan ada hubungan antara usia pubertas dengan kejadian gingivitis. Peningkatan hormon endokrin yang lebih tinggi menunjukkan risiko gingivitis yang lebih besar. Tabel 1 menunjukkan bahwa skor gingivitis pada pubertas lebih tinggi dibanding dengan skor gingivitis pada prapubertas. Hal tersebut disebabkan karena perbedaan keadaan endokrinologik dan adanya fluktuasi hormon seksual yang merupakan salah satu faktor dalam perubahan inflamasi pada gingiva.

Hasil penelitian ini sesuai dengan penelitian yang telah dilakukan oleh Luthfi 
tahun 2014 di SMP Ta'mirul Islam Surakarta yang menunjukkan adanya perbedaan nilai status kesehatan gingiva antara prapubertas dan pubertas dan didapatkan bahwa status kesehatan gingiva pada prapubertas lebih baik dibandingkan dengan pubertas. ${ }^{10}$

Angka kejadian gingivitis pubertas lebih tinggi dibandingkan dengan prapubertas. Hal ini disebabkan karena aktivitas kelenjar hormon yang meningkat, sehingga hormon estrogen, progesteron dan androgen meningkat tajam selama pubertas.

Pada masa pubertas jumlah estrogen yang disekresi meningkat 20 kali atau lebih. Gingiva merupakan tissue target dari hormon steroid. Perubahan klinis pada jaringan periodontal tampak selama periode fluktuasi hormon. Pengaruh utama hormonhormon tersebut terhadap jaringan periodontal estrogen mempengaruhi salivary peroxidase, yang bisa memberikan perlawanan aktif terhadap mikroorganisme, estrogen menstimulasi metabolisme kolagen dan angiogenesis, estrogen dan progesteron mempengaruhi respon vascular dan jaringan ikat pada periodonsium, yang berhubungan dengan mediator inflamasi. ${ }^{11}$

Jumlah Capnocytophaga dan

Prevotella intermedia meningkat dan diikuti oleh berkembangnya gingivitis. Peningkatan dari Prevotella intermedia terjadi bersamaan dengan meningkatnya kadar hormon estrogen dan progesteron. Estrogen dan progesteron merupakan faktor pertumbuhan yang esensial bagi Prevotella intermedia. Provotella intermedia mampu menggantikan estrogen dan progesteron untuk menadione (vitamin K) sebagai nutrisi penting. Jumlah bakteri plak bertambah karena meningkatkan aliran cairan gingiva. Bakteri dapat tumbuh dan berkembang biak apabila berada pada lingkungan yang sesuai dan tersedianya nutrien. Semakin banyak cairan krevikular gingiva, maka semakin banyak pula nutrisi yang tersedia bagi pertumbuhan bakteri. ${ }^{12,13}$

$$
\text { Meningkatnya hormon endokrin }
$$
disertai dengan perubahan vaskuler menyebabkan gingiva menjadi lebih sensitif khususnya terhadap toksin maupun iritan lainnya seperti plak dan kalkulus yang mengakibatkan keradangan pada gingiva. Seperti yang telah lama diketahui, hormon adalah pengatur spesifik yang mempunyai efek yang kuat pada perkembangan integritas skeleton dan rongga mulut, termasuk di dalam jaringan periodontal yakni gingiva.

Hormon endokrin mempunyai pengaruh yang signifikan pada sistem organ yang berbeda. Pada gingiva hormon ini dapat mempengaruhi proliferasi seluler, diferensiasi, serta pertumbuhan keratinosit dan fibroblas. Estrogen terutama bertanggung jawab untuk perubahan dalam pembuluh darah dan progesteron merangsang produksi mediator inflamasi. ${ }^{14,15}$

Faktor lain yang dapat menyebabkan tingginya angka kejadian gingivitis pada pubertas dibandingkan dengan prapubertas adalah tingkat stres. Saat stres muncul, kadar hormon kortisol akan meningkat, dan sistem kekebalan 
terganggu sehingga bakteri leluasa menyerang gingiva. Stres bisa memicu seseorang untuk lebih banyak melakukan kebiasaan yang merugikan rongga mulut, bahkan mungkin mengabaikan kesehatan mulutnya. Tingginya level stres disertai dengan kurangnya kesehatan rongga mulut dapat mengakibatkan perdarahan pada gingiva yang meningkat. ${ }^{16}$

\section{KESIMPULAN}

Angka kejadian gingivitis antara prapubertas dan pubertas terdapat perbedaan dengan angka signifikansi $\mathrm{p}=$ $0,006(p<0,05) R=0,349$. Kejadian gingivitis pada prapubertas di SDN Madyopuro 6 lebih rendah dibandingkan dengan gingivitis pada pubertas di SMPN 22 Malang.

\section{DAFTAR PUSTAKA}

1. Manson JD, Eley BM. Buku Ajar Periodonti. Edisi 2. Jakarta: Hipokrates; 2013: p.44-53.

2. Lang NP, Schatzle MA, Loe H. 2009. Gingivitis as A Risk Factor In Periodontal Disease. J Clin Periodontal. 2009; 36(10): 3-8.

3. Jurgen B, Angelika D. Disorders of Pubertal Development. Deutsches Arztebl Int. 2009; 106(17): 295-304.

4. Nield-Gehrig, Jill SW, Donald E. 2011. Foundation of Periodontics for the Dental Hygienist. $3^{\text {rd }}$ Edition. Amerika Philadelphia: Lippincott Williams \& Wilkins; 2011: p. 269-27.
5. Jeffrey $A D$, Avery $D R$, McDonald RE. Dentistry for the Child Adolescent. $9^{\text {th }} \mathrm{Ed}$. Missouri: Mosby; 2011: p.376, 380-3.

6. Khaled AH, Ibrahim, Yahia T, Al-Hadad, Ahmed MA, Nezar N. 2013. Assessment of Gingival Health Status among 5- and 12-Year-Old Children in Yemen: A CrossSectional Study. ISRN dent. 2013; 1-7.

7. Mishu MP, Hubbard RM, Haque S. Gingivitis in Primary School Children of Bangladesh. Ibrahim Med. Coll. J. 2009; 3(2): 71-74.

8. Notoatmodjo S. Metodologi Penelitian Kesehatan. Jakarta: Rineka Cipta; 2012: p. 36.

9. Panagakos, Fotinos S, Davies R. 2011. Gingival Disease Their Aetiology Prevention and Treatment. London: Intech; 2011: p176.

10. Luthfi, R. 2014. Perbedaan Status Kesehatan Gingiva pada Prapubertas dan Pubertas di SD SMP Ta'mirul Islam Surakarta. Universitas Muhammadiyah Surakarta

11. Lindhe J, Lang NP, Karring T. Clinical Periodontology and Implant Dentistry. $5^{\text {th }}$ Edition. Blackwell Munksgaard.

12. Newman MG, Takei HH, Caranza FA. Clinical Periodontology. $12^{\text {th }}$ Ed. Tokyo: W.B. Saunders Company. 2015

13. Hagen, Casper P, Aksglaede L, Sorensen K, Anders J. Individual Serum Levels of Anti-Mullerian Hormone in Healthy Girls Persist through Childhood and Adolescence 2a Longitudingal Cohort Study. Human Reproduction. 2012; 27(3): 861-6. 
14. Mealey BL, Moritz AJ. 2003. Hormone Influences: Effects of Diabetes Mellitus Endogenous Female Sex Steroid Hormones on the Periodontium. Periodontol 2000. 2003; 32: 59-81.

15. Beauchamp TL, Childress JF. Principles og Biomedical Ethic. $7^{\text {th }}$ Ed. New York: Oxford University Press; 2009: p.38.

16. Larasati, R. Pengaruh Stres pada Kesehatan Jaringan Periodontal. Jurnal Skala Husada. 2016; 13(2): 81-9. 